\title{
RESTORATION OF THE QUEEN VICTORIA MARKET SHEDS E-F AND J-M, MELBOURNE, AUSTRALIA
}

\author{
JUSTIN C. HETTINGA ${ }^{1 *}$ \\ ${ }^{1}$ Robert Bird Group Pty Ltd \\ Tower 4 Collins Square, Level 19727 Collins Street, Melbourne VIC 3008 Australia \\ e-mail: justin.hettinga@robertbird.com.au, www.robertbird.com (*corresponding author)
}

Keywords: Historical Structure, Conservation and Restoration, Case Study, $19^{\text {th }}$ Century Architectural Heritage, $20^{\text {th }}$ Century Architectural Heritage

\begin{abstract}
This paper discusses the investigations, analysis, and proposed strengthening to Sheds E-F and J-M of the Queen Victoria Market in Melbourne, Australia. The sheds were visually inspected and measured, a point cloud survey was carried out, wind tunnel testing determined design pressures, and timber samples determined species, grade and extent of deterioration. Strengthening designs were in accordance with the Burra Charter - The Australia ICOMOS Charter for Places of Cultural Significance 2013.
\end{abstract}

\section{INTRODUCTION}

The City of Melbourne became aware of potential structural deficiencies of sheds at the Queen Victoria Market and decided to undertake a full assessment of all heritage structures at the site to ensure their safety and longevity. Robert Bird Group was engaged to perform a structural assessment of selected sheds and design any required strengthening.

In this paper a brief history and chronology of the site is provided, followed by a description of the investigations, testing, monitoring and analysis that was carried out. The results and proposed strengthening are described, followed by commentary on the project.

\section{HISTORICAL OVERVIEW}

\subsection{Historical significance}

The Queen Victoria Market is a major landmark and tourist attraction in Melbourne, Victoria, Australia, and at seven hectares is the largest open-air market in the southern hemisphere. It has been in continual operation since the 1870 s and from a group of central markets built by the corporation of the City of Melbourne during this period, it is the only one surviving.

The site also served as Melbourne's first official cemetery, Melbourne Cemetery, and was in use from 1837 to 1854 , then intermittently until being closed in 1917. It is listed on the Victorian Heritage Register, in part due to its importance to the course of Victoria's cultural Heritage. [1]

As an estimated 6,500 to 9,000 burials remain on the site, it is of archaeological significance and has the potential to provide information about Aboriginal and European communities and 
their burial practices and customs in early Melbourne. [1]

The site is valued for its demonstration of the principle characteristics of a class of cultural places and objects, namely the produce market. The purpose-built nineteenth and early twentieth century buildings are largely intact, and the predominately utilitarian style adopted for marketplaces at the time is evident.

Due to its ongoing use and continued popularity as a fresh food market and meeting place for locals and tourists, the market is considered socially significant.

\subsection{Chronology}

Prior to European settlement, the area where Melbourne is now located was home to the Kulin people. Their ancestors lived in the area for an estimated 40,000 years and the population was estimated to be under 20,000. [2] European exploration occurred between 1797 and 1834, and in 1835 John Batman explored large areas of what is now Melbourne. On 6 June 1835, he signed a treaty with the indigenous Wurundjeri elders, purportedly buying 600,000 acres of land around Melbourne. [3] Settlement of the area followed, and two years later in 1837 ten acres of land were set aside for what would become the Melbourne Cemetery. The Cemetery was surveyed by Robert Hoddle, who also surveyed and laid out the central business district of Melbourne. It had sections for Presbyterian, Episcopalian, Roman Catholic, Wesleyan, Jewish, Independent, Society of Friends (Quaker) and Aboriginal burials.

In 1853, the Melbourne General Cemetery in Carlton opened, allowing for the closure of Melbourne Cemetery in 1854 due to concerns over people living increasingly closer to it as the city grew. Following it continue burials until 19 buried in the cemetery

The eastern triangular block was granted to as a market, and a meat
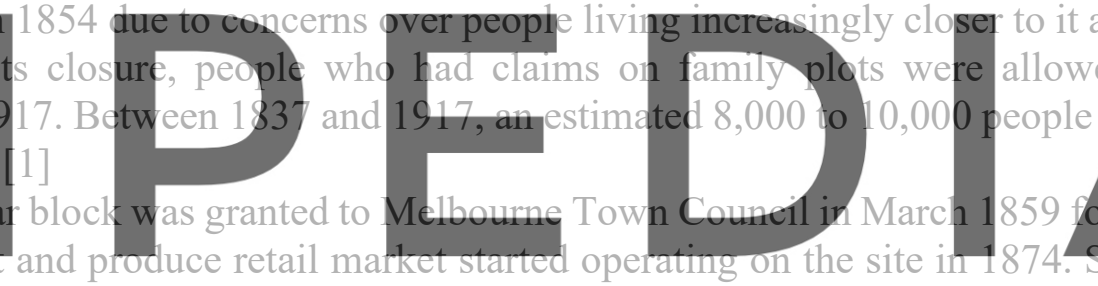

$\mathrm{H}$ and I were built for fruit and vegetable growers to operate and in 1877, legislation granted

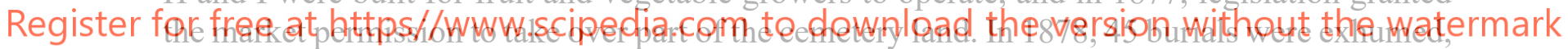
and sheds A-F were constructed. Sheds A-E were open on all sides, and shed F had a brick wall constructed on its southern side to divide the market from the remainder of the cemetery. [1]

In March 1878, the market was officially opened as 'Queen Victoria Market.' In 1884 twostorey terrace shop buildings were built along Elizabeth Street, then in 1887 along Victoria Street. Between 1890 and 1905, additional shops were constructed along Victoria Street, and subsequently under 1917 legislation the remainder of the cemetery was acquired by the market. [1]

From 1920 to 1922,914 bodies were exhumed and relocated, including the remains of John Batman, to Fawkner Cemetery. Sheds K and L were constructed in 1923, the Dairy Produce Hall was constructed in 1928, and the two rows of sixty brick stores comprising Market Square were constructed in 1929-1930 to provide storage for market traders. Shed M was constructed in 1936 and Shed J was constructed in 1991. [1]

A layout of the sheds is shown in Figure 1. 


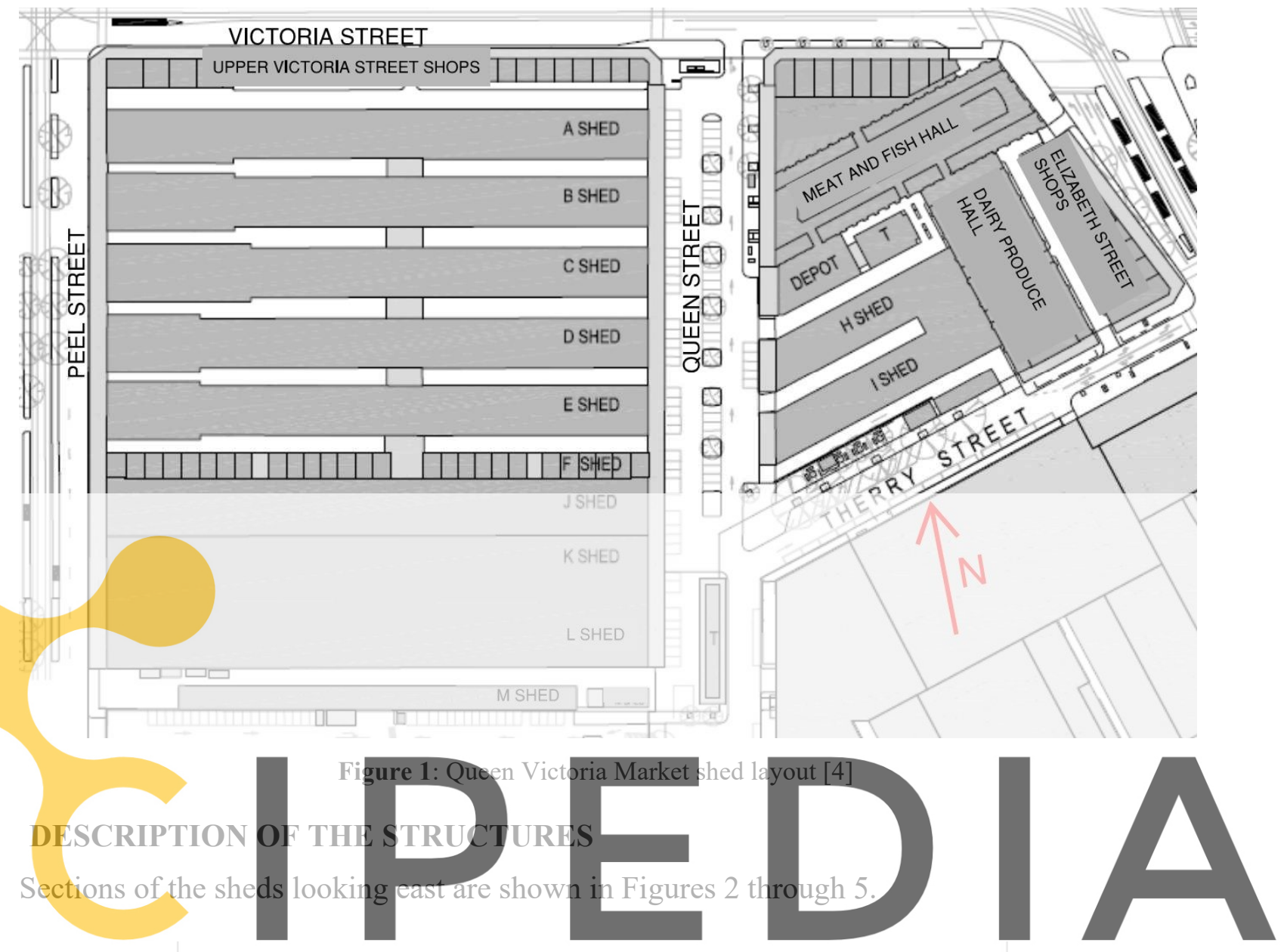

Register for free at https//www.scipedia.cóm to down wa åd the version without the watermark

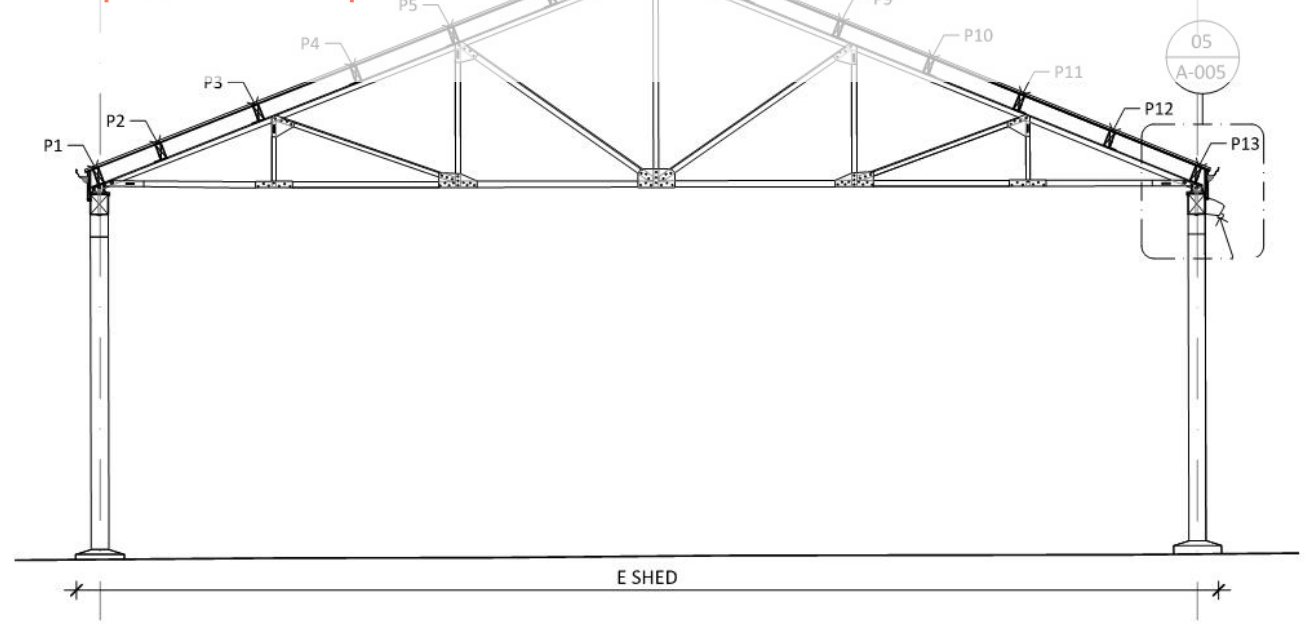

Figure 2: Shed E framing elevation [5] 


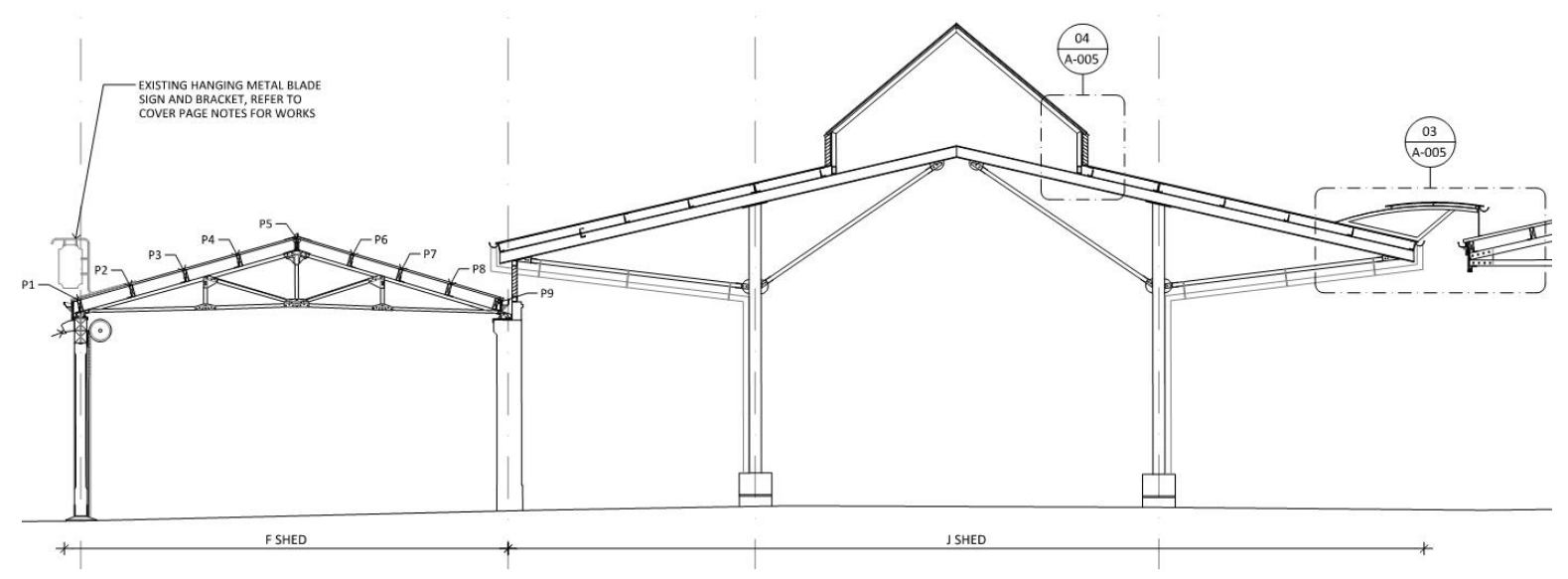

Figure 3: Shed F and J framing elevation [5]

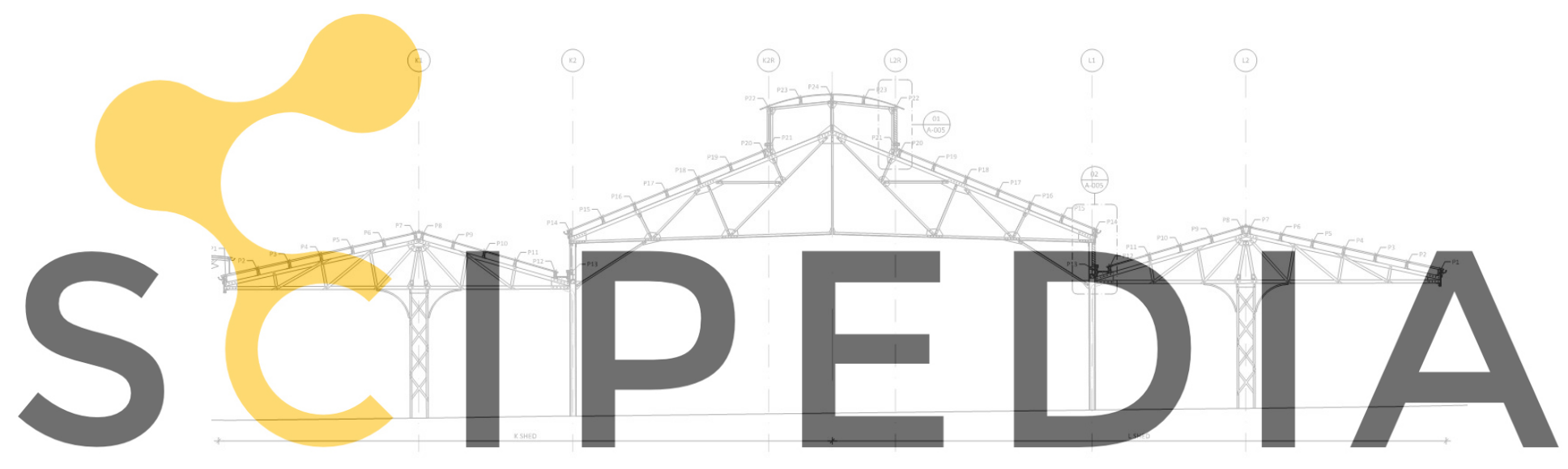

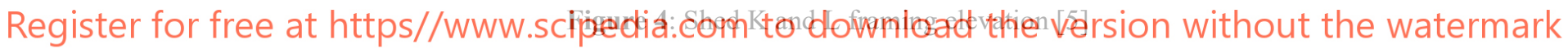

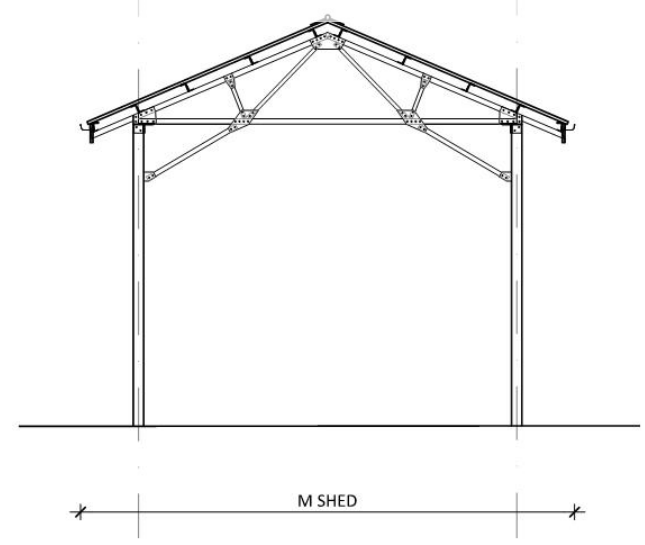

Figure 5: Shed M framing elevation [5]

Shed $\mathrm{E}$ has metal roof sheeting supported by timber purlins, steel roof trusses, timber beams, timber posts and pad footings and is shown in Figure 2. The metal roof sheeting and shallow 
footings are common across all sheds.

Shed F has the same framing as Shed E, apart from the southern wall which is unreinforced brick masonry on a strip footing instead of timber beams and posts on pad footings. An elevation of Shed F looking east is shown in Figure 3.

In the north-south direction of Shed E, knee-bracing on every second truss provides lateral stability. Shed F has timber framed infill walls between tenancies and therefore does not have knee-bracing. In the east-west direction of both sheds, portal frame action was achieved from the bolts and haunch at the beam-column connection, shown in Figure 6.

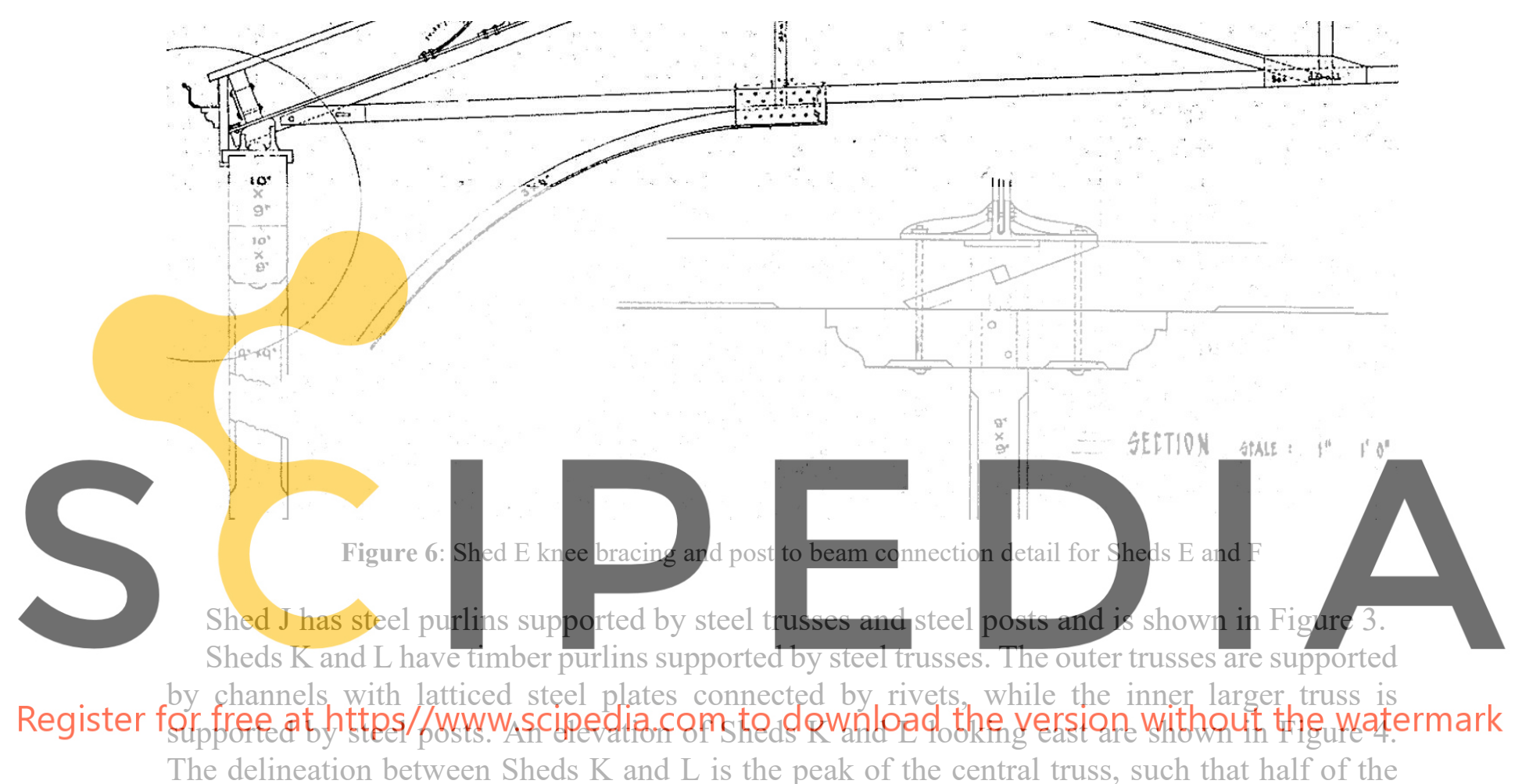

central truss is in Shed $\mathrm{K}$ and the other haif in Shed L. This delineation is soleiy for the layout of market stalls.

Shed M has steel purlins on steel trusses supported by steel posts and is shown in Figure 5.

All sheds act independently and are structurally isolated from one another, except for Sheds $\mathrm{K}$ and $\mathrm{L}$ which together form one structure.

Short canopies constructed with steel purlins, beams and posts provide shade to the footpath along the ends of the sheds, along both Peel Street and Queen Street.

\section{INVESTIGATIONS AND DATA COLLECTION}

\subsection{Determination of applicable building code and level of compliance}

Previously, Sheds A to D were analysed as part of a separate project which determined they had insufficient structural capacity and could pose a safety risk. The site owner and custodian therefore decided to assess all the sheds across the market, resulting in this project. To mitigate the risk to a measurable level, a building surveyor was engaged to determine the required level 
of compliance.

The building surveyor selected the current Australian building code, the National Construction Code 2019 (NCC), for use on the project in accordance with relevant building legislation. They provided a concession on the structural adequacy requirements by setting the level of required compliance at $80 \%$ of code values. This concession took into consideration that building codes differed at the time of construction.

As the NCC uses limit states design, the reduction was applied to the wind loading pressures as it was deemed to be the most appropriate method.

\subsection{Existing drawing search}

The National Archives of Australia were accessed, and a building plan and documentation search was conducted at the City of Melbourne to locate available drawings.

Structural drawings of Shed F, architectural drawings of Shed J, structural drawings of Sheds $\mathrm{K}$ and L, and an architectural section of Sheds K and L were supplied.

\subsection{Visual survey and measurements}

A full visual survey and measurement was carried out of the existing structures. The roof trusses and canopy roof framing of the sheds are exposed on the underside and easily accessed with boom and scissor lifts. A tape measure, laser measure, and caliper were used to measure member spans and sizes. Damage and deterioration to members were recorded with the aid of

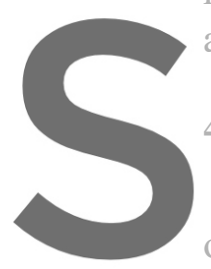
a marking plan to denote locatio

4.4 Point cloud survey

A point cloud survey
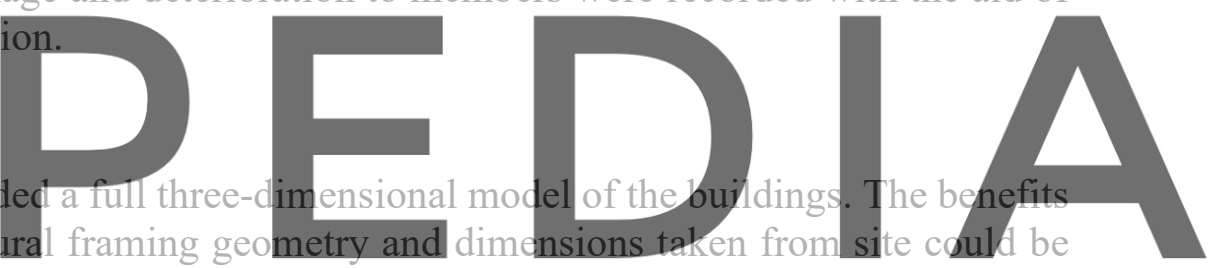

verified in the office and any photos or measurements that were missed during the investigation

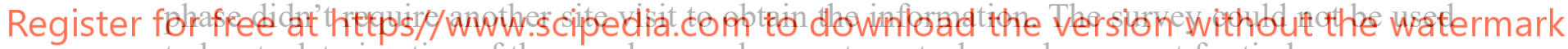
to locate deterioration of the members such as rust on steel members or rot for timber, nor was it to the degree of detail required to measure cross sectional dimensions of slender members and connections. A screenshot from the point cloud survey is shown in Figure 7. 


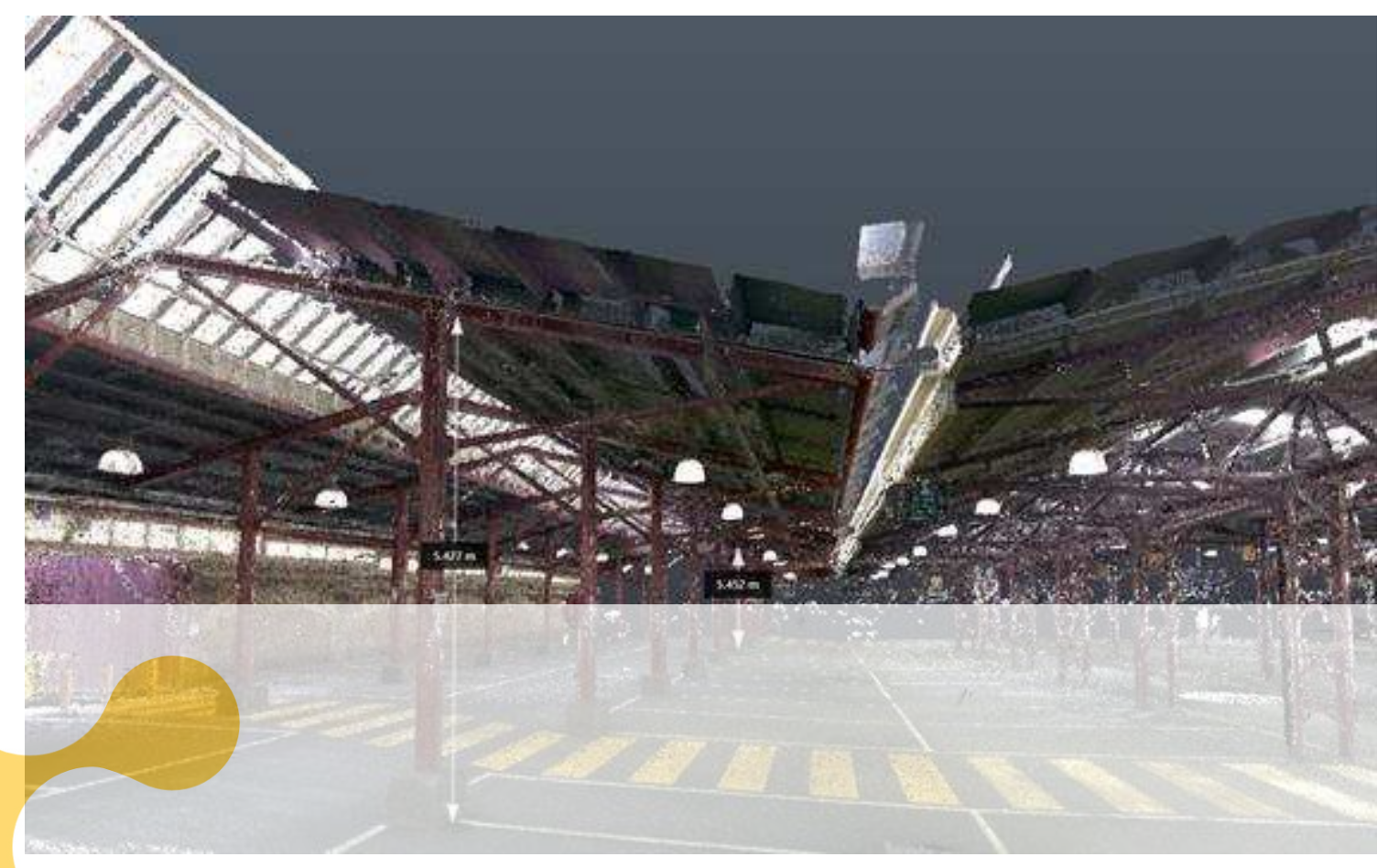

Figure 7: Point cloud generated image. From left to right the back wall of Shed F, Shed J, and the north end

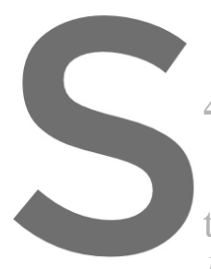

4.5 Wind tumnel testing
Wind tunnel testing wa
the wind loadings from th
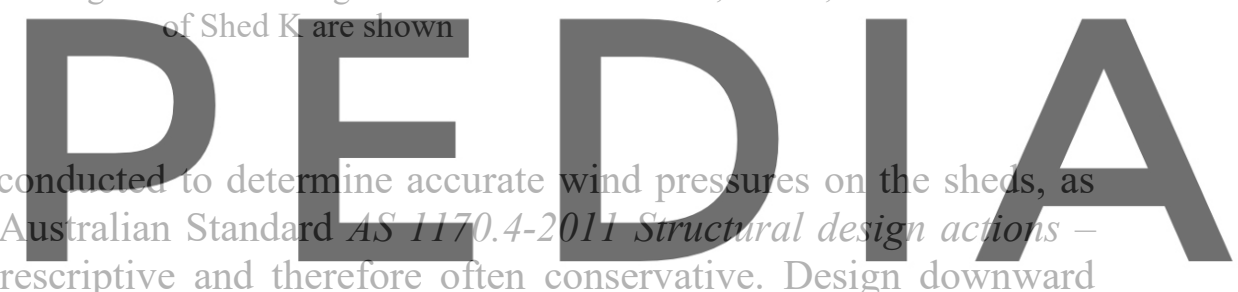

Regisures were reduced from $0.31 \mathrm{kPa}$ to $0.23 \mathrm{kPa}$, and upliftpressures reduced from $0.59 \mathrm{kPa}$

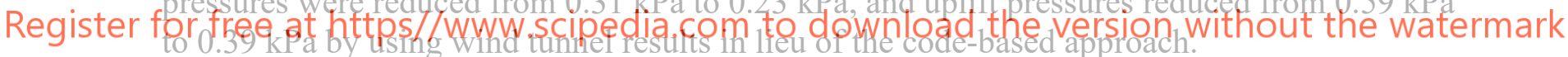

\subsection{Investigation of timber members}

Timber specialists from the University of Tasmania conducted a full assessment of the structural timber members across the sheds. Columns were identified as River Red Gum (E. camaldulensis) and beams and purlins were identified as Douglas Fir (Pseudotsuga menziesii). Species identification was confirmed by laboratory testing of samples. Members were graded to Australian Standards AS 2082-2007 Timber - Hardwood - Visually stress-graded for structural purposes and AS 2858-2008 Timber - Softwood - Visually stress-graded for structural purposes, and the majority were determined to be Structural Grade No. 1. The corresponding stress grade for beams, purlins and columns was determined to be F17, which defines the bending strength, tension strength, compression parallel to grain strength and short duration modulus of elasticity values.

Timber members with damage or deterioration were identified by the timber specialist and where required, the depth of damage was determined with a small diameter core sample. 


\subsection{Structural analysis}

Sheds were analyzed using Space Gass finite element analysis software using both two and three-dimensional models as applicable. Results were independently verified with hand calculations.

\section{RESULTS AND INTERVENTIONS}

\subsection{Analysis results}

Overall, the sheds were found to be structurally compliant to the $80 \%$ of code value limit set out by the building surveyor, with the exception of the lateral stability of Sheds $\mathrm{E}$ and $\mathrm{F}$ in the north-south direction, and the trusses of Sheds E, F and J under wind uplift loading.

The sheds were all built before seismic design requirements were introduced in the 1994 Building Code of Australia. However, as the sheds have little mass wind loads governed in all cases except for the Shed F masonry wall.

\subsection{Sheds E and F lateral stability}

Building drift under wind load exceeded code recommendations but was deemed to not be of concern.

The lateral capacity of the sheds in the east-west direction was found to be insufficient as the bending moments in the connections exceeded their design strength. To rectify this, a

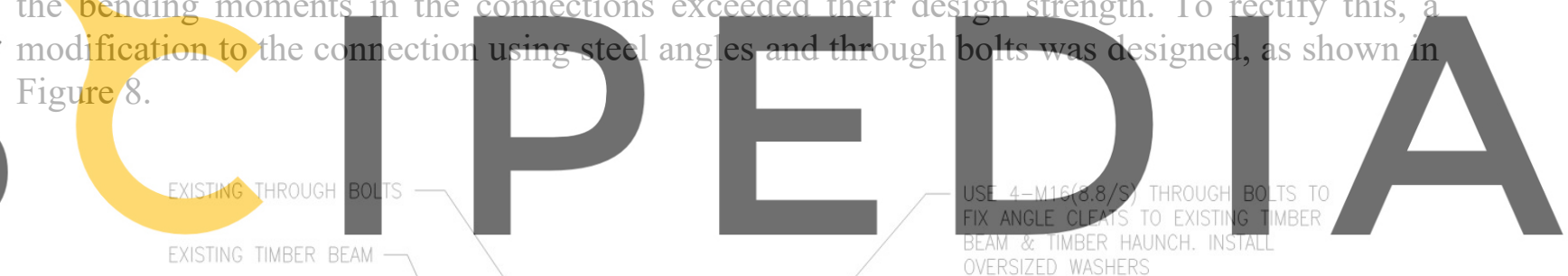

Register for free at https//www.scipedia.com to download the version without the watermark

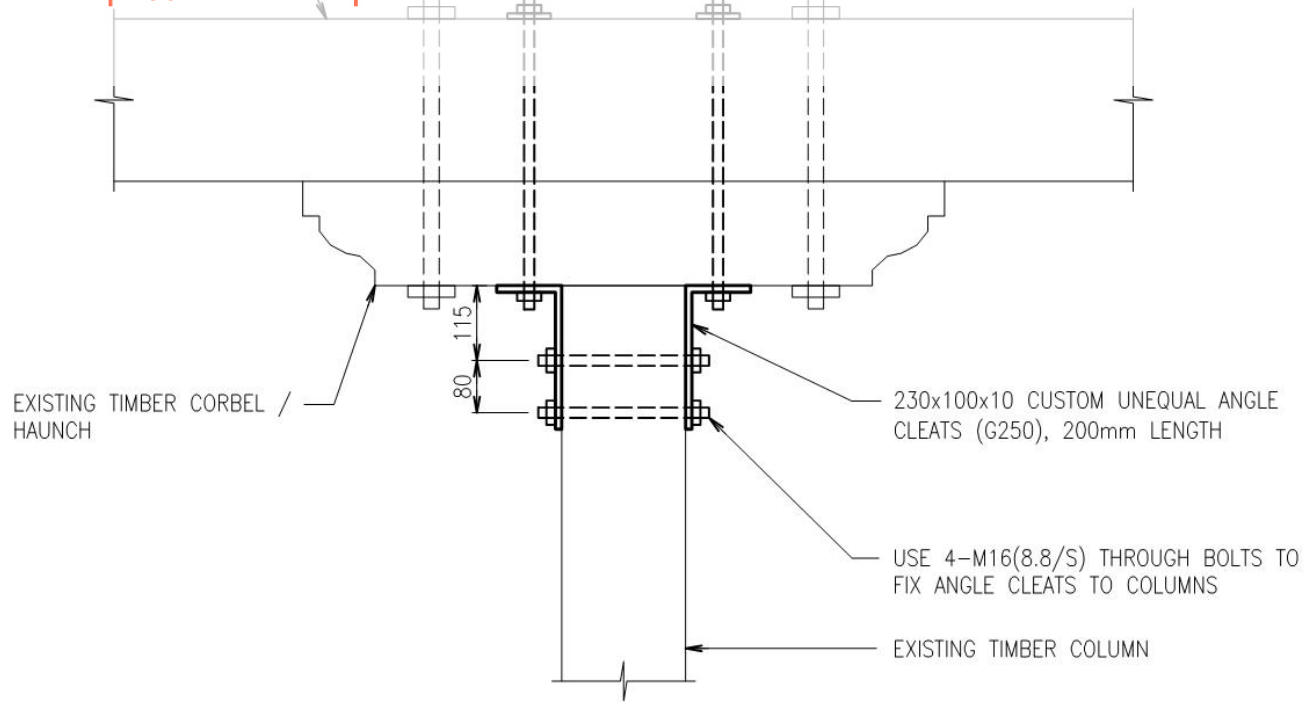

Figure 8: Strengthening detail for Sheds E and F timber haunch 


\subsection{Shed F masonry wall stability}

The masonry wall at the back of Shed F was visibly out of plumb and leaning towards the south, which was confirmed by the point cloud survey. Monthly surveys were undertaken over a six-month period, which determined that no further movement was occurring. Figure 9 shows the survey results for lateral displacement of the top of the wall.
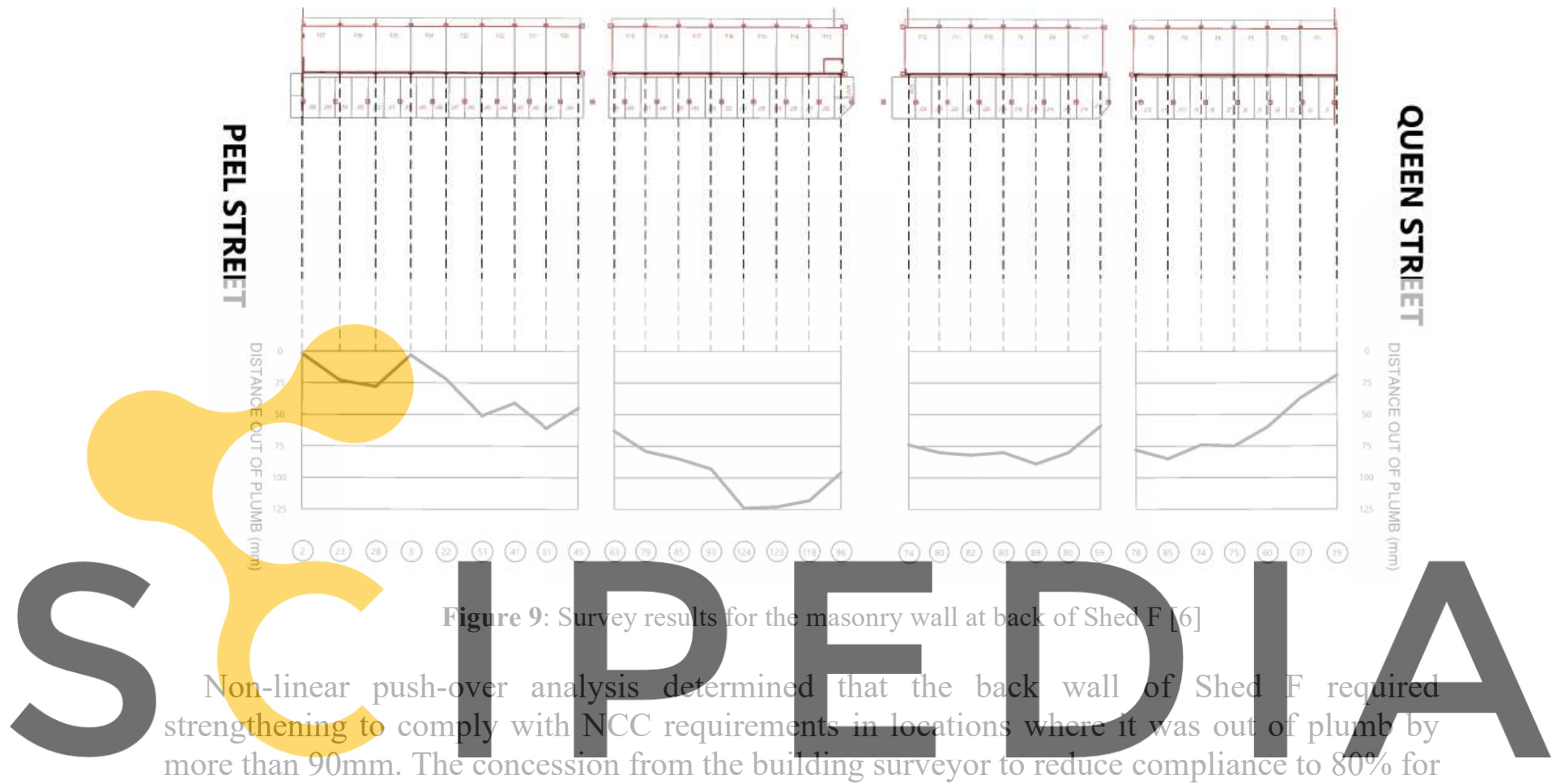

structural adequacy removed the need for strengthening to the wall. However, the design

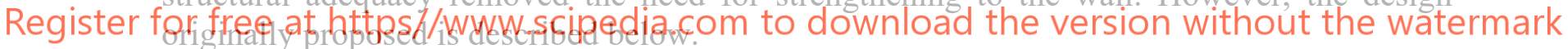

Buttresses on the south side of the masonry wall were designed so that the wall would bear

on them in an earthquake. The buttresses would be on the exterior of Shed $F$ to avoid interfering with the tenancies and have shallow pad footings extending partially above ground to avoid interfering with graves. The buttress to wall interface was detailed with rubber bearing pads such that the wall could lean against the buttresses without any physical attachment between them, making the proposed intervention entirely reversable.

\subsection{Sheds E, F and $\mathbf{J}$ wind uplift case}

The trusses were found to be structurally inadequate under the wind uplift design case, as the uplift pressures were enough to put the bottom chords of the trusses into compression. As the bottom chords were tension-only flat-plate members, they did not have any appreciable compression capacity.

The metal roof sheeting requires replacement as it has reached the end of its design life and was deemed to be unrepairable by the heritage consultant. By adding layers of plywood and fibre cement sheet between two layers of metal sheeting, the new panels add weight onto the trusses to prevent compression from occurring in the truss bottom chords in a wind uplift event. 
The design masses of the replacement roof sheeting varied depending on the shed, with the maximum being $40 \mathrm{~kg} / \mathrm{m}^{2}$. The secondary benefit of the built-up roof panel is that insulation can be provided to the sheds, increasing occupant comfort during summer days when temperatures around 40 degrees Celsius are not uncommon.

Other than the roof sheeting, there were no other lateral stability elements in the plane of the roof. The replacement roof sheeting build-up was therefore designed as a diaphragm. In Australia, steel cladding systems are commonly made from thin high strength steel, and steel design codes do not currently provide guidelines for the design of crest-fixed steel roof or wall claddings. [7] As the steel roof sheeting is being custom-made for this project, it was designed and specified using CAN/CSA-S136-01 North American Specification for the Design of ColdFormed Steel Structural Members. The crest-fixing of the composite roof decking panel to the purlins resulted in the screw being placed in bending, which was accounted for in the design. A detail of the roof build-up at the metal deck splice location is shown in Figure 10.

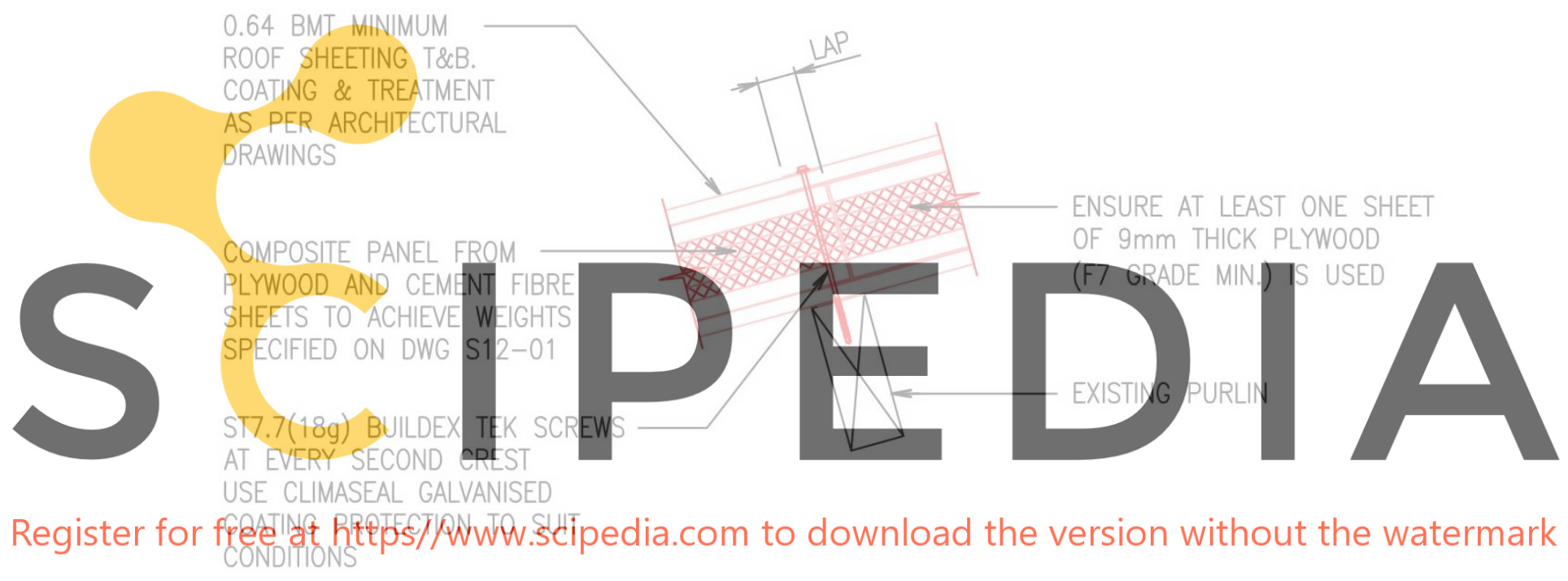

Figure 10: Replacement roof sheeting detail at purlins

\subsection{End walls of Sheds $K$ and $L$}

Lightweight sheeting encloses the ends of Sheds $\mathrm{K}$ and L between the top of the end truss and canopy roof. To verify structural capacity of this partial end wall under wind load, including preventing out of plane buckling of the truss, the columns were checked as cantilevering off the canopy roof diaphragm as shown in Figure 11, and found to be sufficient. 


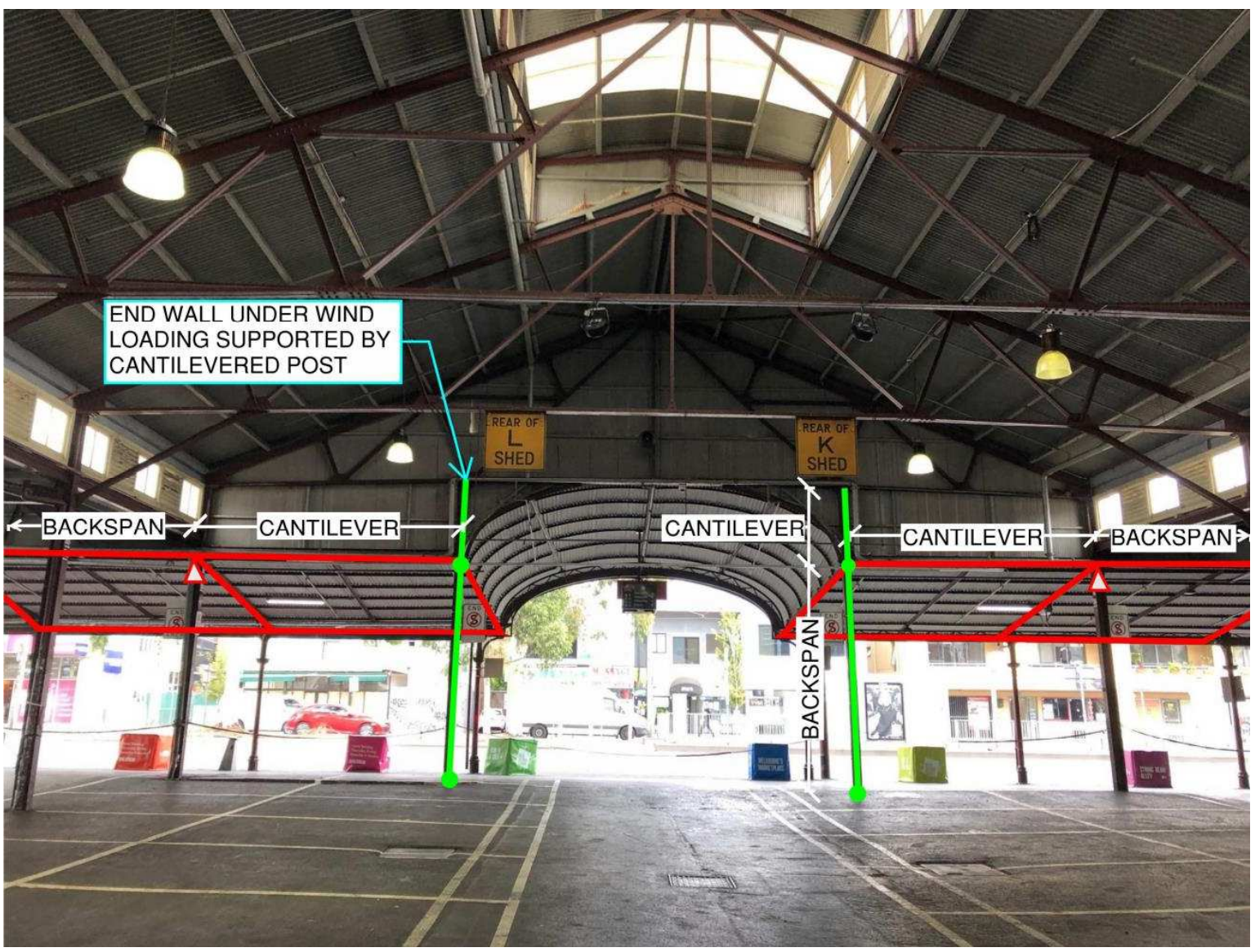

Figure 11: West end of Sheds K and L

\subsection{Replacement of damaged members}

Given its use as a busy market, there are numerous locations of local damage to the structure. The sheds are used as a car park on non-market days, forklifts transport goods through the sheds for market set up, and various lights, sound equipment, and other items are hung from the trusses regularly. Vehicle damage is evident on multiple vertical supports. There are also locations where members have been locally cut to allow for services like downpipes to be installed.

During the visual inspection, a register of members to be repaired or replaced was created.

\subsection{Timber member repairs}

A few timber columns require partial replacement due to significant rot and deterioration. The cause of the deterioration in most cases was a broken downpipe, which resulted in the base of the column undergoing multiple wet-dry cycles over time. Repair of downpipes is being undertaken in conjunction with the partial post replacements.

\section{CONCLUSIONS}

In order to minimize interventions, close collaboration across the project team was required. The wind tunnel testing was instrumental in reducing the design loads and strengthening. 
The concession from the building surveyor to reduce the compliance level from the modern building code was equally important.

Replacement of the roof sheeting with heavier built-up sections was not a favorable outcome due to it being a change to the original design. However, it was preferred when compared to the extensive strengthening that would be required in the form of welding steel plates to existing truss members, had it not occurred. The new built-up roof panels have the same metal roof sheeting profile as the originals but are an observable replacement of the original upon close inspection.

At the time of writing, the tender period for the project is underway and construction works are planned to commence in mid-2020.

Drawings of the project will be stored on file at city council and will remain accessible to the general public like other existing drawings of the market.

ACKNOWLEDGEMENTS. The project team is acknowledged for their expertise and close collaboration on the project:

Heritage consultant and architect: Lovell Chen

Owner and site custodian: City of Melbourne

Timber specialist: University of Tasmania

Building surveyor: Du Chateau Chun

Wind consultant: Mel Consultants

Robert Bird Group project team: Michael Grey, Granil Guerra and Robert Dragwidge

\section{REFERENCES}

[1] Heritage Council Victoria. Victoria Heritage Database. Queen Victoria Market. [Accessed 2019 December 8]. https://vhd.heritagecouncil.vic.gov.au/places/1211.

[2] Gary, P. The First Residents of Melbourne's Western Region, (revised edition). Harriland Press, (1997) ISBN 0-646-33150-7.

[3] Isabel E. and Peter C. People of the Merri Merri, The Wurundjeri in Colonial Days. Merri Creek Management Committee, (2001) ISBN 0-9577728-0-7.

[4] City of Melbourne. QVPR Program Conservation Architect and Heritage Consultant Services. Statement of Works - MSA \#3575, (2019) pp. 9.

[5] Lovell Chen Pty Ltd. Queen Victoria Market Sheds E, F, J, K, L \& M, Project No. 7947, Drawing No. A-004, Revision HV1, (February 2019).

[6] Reeds Consulting. Queen Victoria Market Cemetery Wall Monitoring February Survey, (21 February 2019) Ref. 22524-A.

[7] Mahaarachchi, D. Behaviour and Design of Profiled Steel Cladding Systems Subject to Pull-through Failures, School of Civil Engineering, Queensland University of Technology, (2003). 